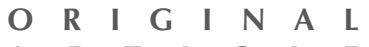

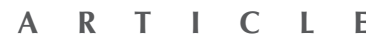

\section{WC Tse 謝慧貞 \\ KY Leung 梁國賢 \\ Beatrice KM Hung 洪傑美}

\title{
Trend of sex ratio at birth in a public hospital in Hong Kong from 2001 to 2010
}

\begin{abstract}
Objectives To identify factors affecting the sex ratio at birth.
Design Cross-sectional study.

Setting Obstetric department of a public hospital in Hong Kong.

Participants All pregnant women delivered between 2001 and 2010.

Main outcome measures Sex ratio at birth versus women's eligibility status, age, parity, number of miscarriages or terminations of pregnancy, and number of fetuses were analysed using the Chi squared test. Multivariate regression was used to determine the effects of multiple factors on the sex of the newborn.

Results A total of 54039 cases were reviewed. The sex ratio at birth changed since 2003, and became unbalanced ( $>107$ males per 100 females) since 2006 revealed by a significant increase in males per 100 females, from 106.6 in 2001-2005 to 111.4 in 2006-2010. From 2001 to 2010, the sex ratio at birth increased from being balanced to becoming unbalanced in eligible persons, and became more unbalanced in non-eligible persons. The ratio increased in eligible persons after having two children, but in non-eligible persons after having one child. The sex ratio at birth was unbalanced (1.095) in singleton pregnancies, but balanced (1.019) in multiple pregnancies. Based on logistic regression, the chance of a male baby being born increased with parity of 2 or above (odds ratio=1.1; $\mathrm{P}<0.001$ ), non-eligible person status (odds ratio=1.05; $\mathrm{P}=\mathbf{0 . 0 3 4}$ ), and delivery in the period 2006-2010 (odds ratio=1.04; $P=0.019)$. The ratio was not increased with advanced maternal age, the number of miscarriages/terminations of pregnancy, and number of fetuses.

Conclusion Compared with 2001-2005, the sex ratio at birth became unbalanced in 2006-2010. An unbalanced ratio ensued in the latter period in both eligible and non-eligible persons, but to a greater extent and even after having one child in the latter group.
\end{abstract}

Key words Birth rate; Hong Kong; Pregnancy; Sex ratio

Hong Kong Med J 2013;19:305-10 DOI: $10.12809 / \mathrm{hkmj} 133858$

Department of Obstetrics and Gynaecology, Queen Elizabeth Hospital, Jordan, Kowloon, Hong Kong WC Tse, MB, BS, MRCOC

KY Leung, FHKCOG, FHKAM (Obstetrics and Gynaecology)

Private Practice BKM Hung, BSocSc (Hons), MPhil

Correspondence to: Dr WC Tse Email: drcathytwc@yahoo.com
New knowledge added by this study

- There was a significant increase in the male/female ratio at birth, in eligible as well as noneligible persons, from a balanced state in 2001-2005 to an unbalanced state $(>107 / 100)$ in 20062010.

- The sex ratio at birth was balanced in women with multiple pregnancies.

- Amplications for clinical practice or policy
gender equality.

\section{Introduction}

A male/female sex ratio at birth (SRB) of greater than 107 males per 100 females is considered high, ${ }^{1,2}$ and will result in, after a few decades, a large excess of men. Consequently, many men will be deprived of marriage and parenting, and thus have adverse effects on the psycho-social well-being of individuals, ${ }^{3}$ societal stability, and security. ${ }^{4}$

Imbalance in the SRB has been found in many countries, mainly in South and East Asia. ${ }^{2}$ In a large population study in China involving 4.7 million persons, the SRB was close to normal for first-order births but was high for second-order births, especially in rural areas, where it reached $1.46 .{ }^{3}$ The strong socio-cultural preference for sons in China is the 


\section{1年至2010年間香港一所公立醫院中出生性 別比率的趨勢}

\begin{tabular}{|c|c|}
\hline 目的 & 討影響出生性別比率的因素。 \\
\hline 設計 & 橫斷面研究。 \\
\hline 安排 & 香港一所公立醫院的產科部門。 \\
\hline 參與者 & 2001 年至 2010 年在本院分婏的孕婦。 \\
\hline 主要結果測量 & $\begin{array}{l}\text { 利用卡方檢驗分析出生性別比率與以下因素的關係: } \\
\text { 本地或非本地孕婦、年齡、產次、流產或終止妊娠的 } \\
\text { 次數, 以及嬰兒數目, 並使用多元回歸分析探討多項 } \\
\text { 因素對嬰兒性別的影響。 }\end{array}$ \\
\hline 結果 & 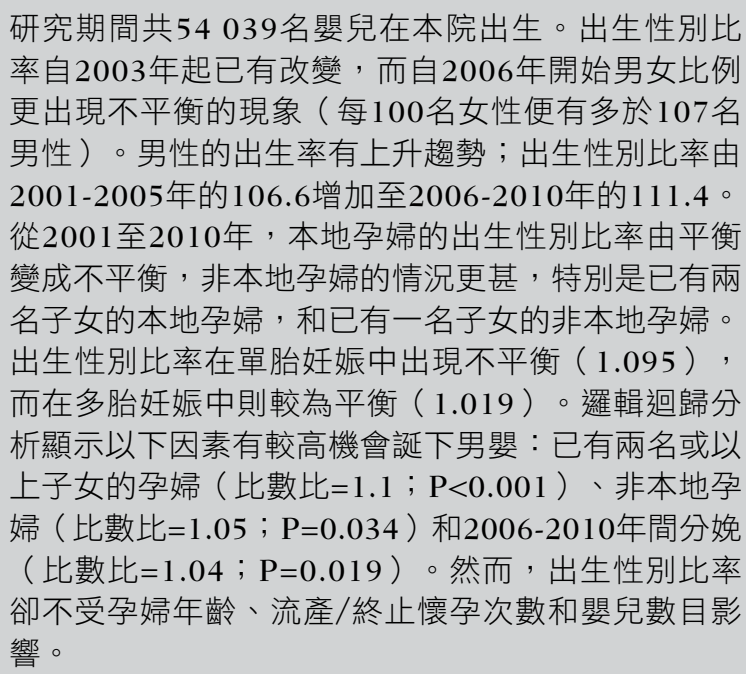 \\
\hline 結言 & $\begin{array}{l}\text { 與 } 2001 \text { 至 } 2005 \text { 年比較, } 2006 \text { 至 } 2010 \text { 年的出生性別比 } \\
\text { 率較為不平衡。2006至 } 2010 \text { 年間無論本地或非本地 } \\
\text { 孕婦, 出生性別比率皆不平衡, 尤以非本地孕婦以及 } \\
\text { 她們當中已有一名子女的更甚。 }\end{array}$ \\
\hline
\end{tabular}

likely underlying reason. The relationship between the SRB and the one-child policy is complex. ${ }^{3}$ In Hong Kong, the one-child policy does not apply and the majority of its citizens (who are Chinese) have been exposed to western as well as Chinese education and culture. Hitherto, whether there was any unbalanced SRB in Hong Kong has not been fully investigated.

In a study on 3356 singleton deliveries in a Hong Kong public hospital from 1996 to 1998, the SRB was balanced in women having their first and second babies, but was high in parity-2 women with two daughters. ${ }^{5}$ The finding of this small-scale study was confirmed by another study of a larger sample size (194 602 babies) collected in several hospitals from 2003 to 2007.4 The SRB in Hong Kong Chinese was 106, 107, and 118 for parity 0 , parity 1 , and parity 2 or above, respectively. ${ }^{4}$ It was suggested that the influx of Mainland Chinese women had exaggerated the male/female birth imbalance in Hong Kong. ${ }^{4}$ Yet, it is not known whether SRB changes over years with maternal age, number of terminations, or in multiple pregnancies. We postulated that the SRB is more balanced in younger mothers as they may not have a strong socio-cultural preference for boys compared with older generations. A high SRB could also be related to persons having termination of pregnancy (TOP) if sex-selective abortion was being practised. Such high ratios may also occur in multiple pregnancies after assisted reproduction technology, if sex selection was also being practised with the procedure.

The objectives of this study were to determine the relationship between the SRB and eligibility status, maternal age, parity, number of miscarriages/ TOP, and multiple pregnancies.

\section{Methods}

This was a retrospective study carried out at Queen Elizabeth Hospital, a tertiary obstetric unit in Hong Kong. The relevant data of all pregnant women who delivered from 2001 to 2010 were retrieved from the Obstetric Clinical Information System, in which the data were entered by midwives and doctors at different time points during the antepartum period and after delivery. The statistics generated from the database was checked regularly. Information on each woman's age, eligibility status, parity, number of miscarriages or TOPs, number of fetuses, and the gender of her babies was collected. Eligible persons (EPs) referred to Hong Kong residents who were eligible to subsidised medical services, while noneligible persons (NEPs) included Mainland Chinese women travelling to Hong Kong to deliver babies. Those with singleton or multiple pregnancies were included. From our database, we could retrieve the total number of TOPs and spontaneous miscarriages, but could not differentiate between them. This study was approved by the Research Ethics Committee of the Kowloon Central Cluster.

The Statistical Package for the Social Sciences (Windows version 15.0; SPSS Inc, Chicago [IL], US) was used for analysis of the findings. The SRBs of all women and in EP and NEP groups were calculated. Besides, cases were subdivided arbitrarily into two periods: 2001-2005 and 2006-2010, because an influx of Mainland mothers after 2005 had resulted in a significant increase in the total number of births in Hong Kong. The patient's eligibility status, age, parity, number of miscarriages or TOPs, number of fetuses, and the gender of the baby were analysed using the Chi squared test. Stepwise multivariate logistic regression was used to determine the effects of multiple factors on the SRB.

\section{Results}

Between 1 January 2001 and 31 December 2010, a total 
of 54039 babies were born in our hospital. There were significant differences in the maternal characteristics in the periods 2001-2005 and 2006-2010 in that there was an increase in the SRB from 106.6/100 to 111.4/100 (Table 1). This ratio increased after 2003 and became unbalanced (>1.07) from 2006 (Fig). While the SRB in singleton pregnancies was $109.5 / 100$ (ie >1.07) in multiple pregnancies it was $101.9 / 100$ or nearly 1 .

Overall, the SRB was greater than $107 / 100$ in both EPs and NEPs, but was greater in the latter (113.0/100) than in the former (108.3/100) [P=0.039; Table 2]. In the EP group, there was a significant increase in the SRB from a balanced level in the period 2001-2005 to an unbalanced level in 2006-2010. In the NEP group, the SRB became more unbalanced from 2001-2005 to 2006-2010. The ratio increased in EP mothers after having two children, but in the NEP mothers it had increased after having one child. On the other hand, the SRB did not change significantly with maternal age or number of TOPs/miscarriages (Table 2).
Using logistic regression, it appeared that the chance having a male baby increased with parity of $\geq 2$ (odds ratio $[O R]=1.1 ; P<0.001)$, NEP status $(O R=1.05$; $\mathrm{P}=0.034)$, delivery during the period 2006-2010 $(\mathrm{OR}=1.04 ; \mathrm{P}=0.019)$, but not with advanced maternal age, number of miscarriages/TOPs, and number of fetuses.

\section{Discussion}

We showed a significant increase in the SRB from a balanced state in 2001-2005 to becoming unbalanced $(>107 / 100)$ in 2006-2010. This was attributed to an increased ratio in both EP and NEP mothers, although it was considerably higher in the latter. Our finding differed from a previous study suggesting that the increase in the SRB was solely attributed to NEPs. ${ }^{4}$ Traditionally, the Chinese have a strong preference for sons, ${ }^{6-10}$ because in olden days they were a source of manual power especially in rural areas. Sons are

TABLE I. Male/female sex ratio at birth and maternal demographics versus period of delivery in Queen Elizabeth Hospital $(n=54039)$

\begin{tabular}{|c|c|c|c|}
\hline \multirow[t]{2}{*}{ Demographics* } & \multicolumn{2}{|c|}{ No. $(\%)^{\dagger}$} & \multirow[t]{2}{*}{$P$ value } \\
\hline & Year 2001-2005 (n=24 539) & Year 2006-2010 (n=29 500) & \\
\hline Male/female SRB (per 100 female births) & 106.6 & 111.4 & $<0.001$ \\
\hline Residency & & & $<0.001$ \\
\hline EPs & $20492(84)$ & $21479(73)$ & \\
\hline NEPs & $4047(16)$ & $8021(27)$ & \\
\hline Age (years) & & & $<0.001$ \\
\hline$\geq 35$ & $4610(19)$ & $6863(23)$ & \\
\hline$<35$ & $19929(81)$ & $22637(77)$ & \\
\hline No. of fetus & & & $<0.001$ \\
\hline Singleton & $23961(98)$ & $28486(97)$ & \\
\hline Multiple & $578(2)$ & $1014(3)$ & \\
\hline Gravida & & & $<0.001$ \\
\hline $1(n=17664)$ & $8342(34)$ & $9322(32)$ & \\
\hline $2(n=17793)$ & $8179(33)$ & $9614(33)$ & \\
\hline $3(n=10482)$ & $4643(19)$ & $5839(20)$ & \\
\hline$\geq 4(n=8100)$ & $3375(14)$ & $4725(16)$ & \\
\hline Parity & & & $<0.001$ \\
\hline $0(n=28733)$ & $13512(55)$ & $15221(52)$ & \\
\hline $1(n=20536)$ & $8888(36)$ & $11648(39)$ & \\
\hline $2(n=3803)$ & $1672(7)$ & $2131(7)$ & \\
\hline$\geq 3(n=967)$ & $467(2)$ & $500(2)$ & \\
\hline Miscarriage/termination of pregnancy & & & $<0.001$ \\
\hline $0(n=30640)$ & $14236(58)$ & $16404(56)$ & \\
\hline $1(n=14522)$ & $6556(27)$ & $7966(27)$ & \\
\hline $2(n=5871)$ & $2540(10)$ & 3331 (11) & \\
\hline$\geq 3(n=3006)$ & 1207 (5) & 1799 (6) & \\
\hline
\end{tabular}

* SRB denotes sex ratio at birth, EPs eligible persons, and NEPs non-eligible persons

+ Unless otherwise specified 


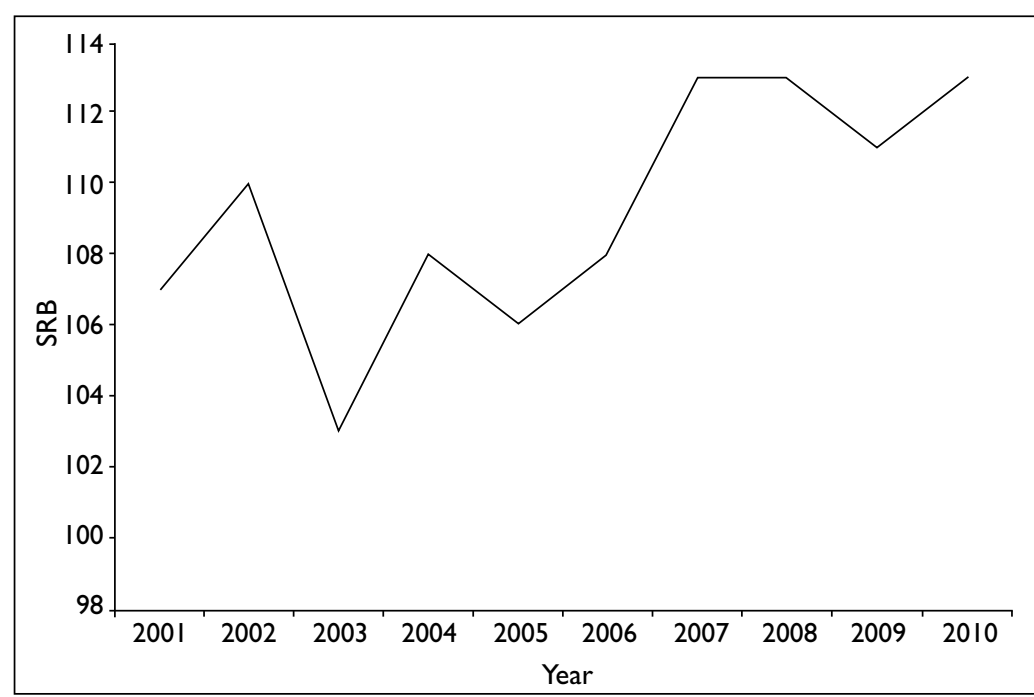

FIG. Trend of male/female sex ratio at birth (SRB) from $200 \mathrm{I}$ to 2010 in Queen Elizabeth Hospital

TABLE 2. Male/female sex ratio at birth and maternal characteristics in eligible persons (EPs) and non-eligible persons (NEPs) in Queen Elizabeth Hospital $(n=54025)^{*}$

\begin{tabular}{|c|c|c|c|}
\hline \multirow[t]{2}{*}{ Characteristic } & \multicolumn{2}{|c|}{ No. (per 100 female births) } & \multirow[t]{2}{*}{$P$ value } \\
\hline & $\begin{array}{c}\text { EPs } \\
(n=41 \text { 959) }\end{array}$ & $\begin{array}{c}\text { NEPs } \\
(n=12 \text { 066) }\end{array}$ & \\
\hline Overall & 108.3 & 113.0 & 0.039 \\
\hline \multicolumn{4}{|l|}{ Year } \\
\hline $2001-2005(n=24531)$ & 106.3 & 108.0 & 0.632 \\
\hline $2006-2010(n=29494)$ & 110.2 & 115.6 & 0.071 \\
\hline$P$ value & 0.032 & 0.041 & \\
\hline \multicolumn{4}{|l|}{ Age (years) } \\
\hline$\geq 35(n=11466)$ & 111.8 & 123.0 & 0.084 \\
\hline$<35(n=42559)$ & 107.2 & 111.6 & 0.071 \\
\hline$P$ value & 0.068 & 0.078 & \\
\hline \multicolumn{4}{|l|}{ Parity } \\
\hline $0(n=28722)$ & 105.1 & 102.8 & 0.449 \\
\hline $1(n=20534)$ & 103.0 & 121.6 & 0.002 \\
\hline $2(n=3802)$ & 120.1 & 153.9 & 0.005 \\
\hline$\geq 3(n=967)$ & 121.4 & 145.5 & 0.383 \\
\hline$P$ value & 0.001 & $<0.001$ & \\
\hline \multicolumn{4}{|l|}{ Miscarriage/termination of pregnancy } \\
\hline $0(n=30632)$ & 106.7 & 114.3 & 0.015 \\
\hline $1(n=14518)$ & 110.9 & 114.3 & 0.445 \\
\hline $2(n=5869)$ & 110.2 & 103.9 & 0.322 \\
\hline$\geq 3(n=3006)$ & 108.9 & 115.5 & 0.345 \\
\hline$P$ value & 0.350 & 0.369 & \\
\hline \multicolumn{4}{|l|}{ Gravida } \\
\hline $1(n=17658)$ & 103.6 & 105.2 & 0.688 \\
\hline $2(n=17787)$ & 108.4 & 113.9 & 0.169 \\
\hline $3(n=10481)$ & 112.0 & 115.4 & 0.518 \\
\hline$\geq 4(n=8099)$ & 114.2 & 122.7 & 0.167 \\
\hline$P$ value & 0.004 & 0.044 & \\
\hline \multicolumn{4}{|l|}{ No. of fetuses } \\
\hline Singleton pregnancies ( $n=52438)$ & 108.3 & 113.7 & 0.019 \\
\hline Multiple pregnancies $(n=1587)$ & 105.3 & 93.4 & 0.284 \\
\hline$P$ value & 0.652 & 0.043 & \\
\hline
\end{tabular}

* The other 14 babies with ambiguous gender were excluded from the analysis expected to produce generations with their family name and look after their parents. The preference for sons is evident in Hong Kong families. ${ }^{4}$ This was despite there being no one-child policy as operated in Mainland China, and the fact that the majority of the local Chinese citizens having been exposed to western as well as Chinese education and culture. The total fertility rate fell steadily in Hong Kong during the past 20 years from the replacement level (ie two children per woman) to a level below one, ${ }^{11,12}$ and this declining fertility rate was associated with an increase in the SRB. ${ }^{13}$ This may explain the increasing ratio in EPs. However, improved economic conditions can lead to a decrease in the country's SRB, as there is a lower demand for manual power, and developed countries have greater acceptance of equal social and economic rights for males and females. ${ }^{10}$ This may also explain our finding of a lower SRB in EPs than in NEPs.

According to the data from Census and Statistics Department in Hong Kong (Table 3), which included deliveries in all public and private hospitals, ${ }^{14}$ the SRB became unbalanced from 2001 which was just when our present study began. We postulate that this might be related to difference in the characteristics of women using public as opposed to private hospitals, as a greater proportion of NEPs delivered in private hospitals. Under the one-child policy, some NEPs chose to delivery in Hong Kong after their first pregnancy. They could also be regarded as more willing to spend money on the pregnancy and deliver in private hospitals, if they knew they carried a male fetus. On the other hand, richer NEPs tend to deliver in private hospitals, no matter the gender of the fetus they were carrying. According to Knight et al, ${ }^{15}$ richer households are more likely to have sons. Probably the SRB was therefore more unbalanced and became so earlier in private hospitals. Only a study in private hospitals can help to clarify this proposition.

Consistent with previous studies, ${ }^{5}$ NEP status and parity of $\geq 2$ were associated with a high SRB. Wong and $\mathrm{Ho}^{5}$ showed that women who had two children of the same gender were more likely to have further pregnancies. They further analysed the relationship of sex compositions in previous pregnancies versus the index pregnancy, and concluded that women with two daughters were more likely to have male newborns.

In our study, the SRB was balanced for multiple pregnancies. Although the present study was limited by a lack of information on the proportion of multiple pregnancies after assisted reproduction, this was a reassuring finding, as applicable sex selection technology probably had not been used locally in assisted reproduction. In Hong Kong, The Council on Human Reproductive Technology is a statutory body established under Section 4 of the Human 
TABLE 3. Male/female sex ratio at birth (SRB) in Hong Kong from 1981 to $2010^{14}$

\begin{tabular}{lccccccccc}
\hline No. of live births & \multicolumn{10}{c}{ Year } \\
\cline { 2 - 11 } & $\mathbf{1 9 8 1}$ & $\mathbf{1 9 8 6}$ & $\mathbf{1 9 9 1}$ & $\mathbf{1 9 9 6}$ & $\mathbf{2 0 0 1}$ & $\mathbf{2 0 0 6}$ & $\mathbf{2 0 0 8}$ & $\mathbf{2 0 0 9}$ & $\mathbf{2 0 1 0}$ \\
\hline Female & 42141 & 34703 & 33084 & 30627 & 23059 & 31031 & 36894 & 38129 & 41218 \\
Male & 44610 & 36917 & 35197 & 32664 & 25160 & 34595 & 41928 & 43966 & 47366 \\
SRB & 105.8 & 106.4 & 106.4 & 106.7 & 109.1 & 111.5 & 113.6 & 115.3 & 114.9 \\
\hline
\end{tabular}

Reproductive Technology Ordinance to regulate the provision of reproductive technology procedures. Sex selection for social reasons is prohibited under the Ordinance, except to avoid or prevent the birth of a child with a severe sex-linked genetic disease. ${ }^{16}$

In our study, there was an increase in the SRB to an unbalanced level (>107/100) in EPs. Although there was an increase in this ratio after having one miscarriage/TOP, this was not confirmed in the logistic multivariate regression. Sex-selective abortion is illegal in Hong Kong and many other countries. Nowadays, fetal sex can be determined non-invasively by two-dimensional ${ }^{17}$ and threedimensional $^{18}$ ultrasonography, and assay of cellfree fetal DNA in maternal plasma (using real-time polymerase chain reaction) after 13,11 , and 7 weeks of gestation, respectively. ${ }^{19}$ Alternatively, karyotyping can be carried out following an invasive procedure (amniocentesis or chorionic villus sampling). However, these medical technologies should not be misused to facilitate sex-selective activities.

The consequences of high SRB should not be overlooked. Many commentators predict that it will lead to increased levels of antisocial behaviour and violence. ${ }^{6}$ More men will remain single. This has been a consistent observation across cultures. Notably, an overwhelming percentage of violent crime is perpetrated by young, unmarried, and lowstatus males. Thus, an imbalance in SRB ultimately presents a threat to the long-term stability and sustainable development of Chinese society. Apart from government policy and law, public education to promote gender equality can help counter this trend. Education can be provided by family members, schools, and governments. ${ }^{20}$ Peoples' attitudes towards this issue are also very important. Monitoring such trends is therefore warranted.

A major limitation of the present study was that the data from only one hospital, and not the whole population, were analysed. However, according to unpublished data from the Department of Health, from June to September 2012 the SRB in our hospital was $107 / 100$, which was comparable to that in all public hospitals (108/100). Second, there was no separate analysis regarding the number of previous TOPs and miscarriages, as corresponding data for each of these conditions logged separately were not available in our database. Grouping of data for number of miscarriages and number of TOPs may mask the effect of selective abortion, if any. Third, for better understanding of the relationship between parity and sex ratio, for multiparous mothers we should have retrieved the gender of previous children.

\section{Conclusion}

Compared with 2001-2005, there was a significant increase in SRB resulting in an unbalanced level in 2006-2010. This ratio was unbalanced in both EP and NEP subjects, but to a greater extent and occurring after having only one child in the latter. Notably, the ratio was not affected by maternal age, the number of miscarriages/TOPs, and number of fetuses.

\section{Acknowledgements}

We thank Ms Angela Au for retrieving the data from our hospital database.

\section{References}

1. James WH. The human sex ratio. Part 1: a review of the literature. Hum Biol 1987;59:721-5.

2. Arnold $F$. The effect of son preference on fertility and family planning: empirical evidence. Popul Bull UN 1987;23:4455.

3. Zhu WX, Lu L, Hesketh T. China's excess males, sex selective abortion, and one child policy: analysis of data from 2005 national intercensus survey. BMJ 2009;338:b1211. cross ref

4. Wong GY, Leung WC, Chin RK. Recent dramatic increase in the male-to-female sex ratio of babies born in Hong Kong. J Perinat Med 2010;38:209-13. cross ref

5. Wong SF, Ho LC. Sex selection in practice among Hong Kong Chinese. Soc Sci Med 2001;53:393-7. cross ref

6. Das Gupta M, Jiang Z, Li B, Xie Z, Chung W, Bae H. Why is son preference so persistent in East and South Asia? A crosscountry study of China, India and the Republic of Korea. J Dev Studies 2003;40:153-87. cross ref

7. Poston DL Jr. Son preference and fertility in China. J Biosoc 
Sci 2002;34:333-47. cross ref

8. Banister J. Shortage of girls in China today. J Popul Res 2004;21:19-45. cross ref

9. Hesketh T, Lu L, Xing ZX. The effect of China's one-child family policy after 25 years. N Engl J Med 2005;353:11716. cross ref

10. Hesketh T, Zhu WX. Abnormal sex ratios in human populations: causes and consequences. Proc Natl Acad Sci U S A 2006;103:13271-5. cross ref

11. Yip PS, Lee J. The impact of the changing marital structure on fertility of Hong Kong SAR (Special Administrative Region). Soc Sci Med 2002;55:2159-69. cross ref

12. Frejka T, Jones GW, Sardon JP. East Asian childbearing patterns and policy developments. Popul Dev Rev 2010;36:579-606. cross ref

13. Guilmoto CZ. Son preference, sex selection, and kinship in Vietnam. Popul Dev Rev 2012;38:31-54. cross ref

14. Hong Kong Census and Statistics Department. Live births by sex. Website: www.censtatd.gov.hk/FileManager/EN/ Content_1149/T01_03_04_C02.xls. Accessed Mar 2013.

15. Knight J, Shi L, Quheng D. Son preference and household income in rural China. J Dev Stud 2010;46:1786-805. cross ref
16. Council on Human Reproductive Technology, Food and Health Bureau. Code of practice on reproductive technology and embryo research; 2007. Available from: http://www.fhb.gov.hk/download/press_and_publications/ otherinfo/021230_h/e_cop_full.pdf. Accessed Mar 2013.

17. Odeh M, Granin V, Kais M, Ophir E, Bornstein J. Sonographic fetal sex determination. Obstet Gynecol Surv 2009;64:507. cross ref

18. Youssef A, Arcangeli T, Radico D, et al. Accuracy of fetal gender determination in the first trimester using threedimensional ultrasound. Ultrasound Obstet Gynecol 2011;37:557-61. cross ref

19. Sedrak M, Hashad D, Adel H, Azzam A, Elbeltagy N. Use of free fetal DNA in prenatal noninvasive detection of fetal RhD status and fetal gender by molecular analysis of maternal plasma. Genet Test Mol Biomarkers 2011;15:62731. cross ref

20. Li S. Imbalanced sex ratio at birth and comprehensive intervention in China. Proceedings of the 4th Asia Pacific Conference on reproductive and sexual health and rights; 2007 Oct 29-31; Hyderabad, India. United Nations Population Fund; 2007. 